\title{
Hyperbaric oxygen in chronic traumatic brain injury: oxygen, pressure, and gene therapy
}

Paul G. Harch

\begin{abstract}
Hyperbaric oxygen therapy is a treatment for wounds in any location and of any duration that has been misunderstood for 353 years. Since 2008 it has been applied to the persistent post-concussion syndrome of mild traumatic brain injury by civilian and later military researchers with apparent conflicting results. The civilian studies are positive and the military-funded studies are a mixture of misinterpreted positive data, indeterminate data, and negative data. This has confused the medical, academic, and lay communities. The source of the confusion is a fundamental misunderstanding of the definition, principles, and mechanisms of action of hyperbaric oxygen therapy. This article argues that the traditional definition of hyperbaric oxygen therapy is arbitrary. The article establishes a scientific definition of hyperbaric oxygen therapy as a wound-healing therapy of combined increased atmospheric pressure and pressure of oxygen over ambient atmospheric pressure and pressure of oxygen whose main mechanisms of action are gene-mediated. Hyperbaric oxygen therapy exerts its wound-healing effects by expression and suppression of thousands of genes. The dominant gene actions are upregulation of trophic and anti-inflammatory genes and down-regulation of pro-inflammatory and apoptotic genes. The combination of genes affected depends on the different combinations of total pressure and pressure of oxygen. Understanding that hyperbaric oxygen therapy is a pressure and oxygen dose-dependent gene therapy allows for reconciliation of the conflicting TBI study results as outcomes of different doses of pressure and oxygen.
\end{abstract}

Keywords: Hyperbaric, Oxygen, Traumatic, Brain, Injury, Concussion, Pressure, Gene, Therapy, Veteran

\section{Background}

Confusion over the conflicting conclusions of recent civilian and United States Department of Defense (DoD) trials of hyperbaric oxygen therapy (HBOT) in the treatment of mild traumatic brain injury (mTBI) persistent post-concussion syndrome (PPCS) [1-6] have focused attention on critical flaws $[7,8]$ in the historical definition of HBOT [9] that beg the question "What is hyperbaric oxygen therapy?" The answer to this question has led to a re-appraisal of HBOT as a dual-component $[7,8]$ gene therapy [7] that is poised to not only change, but also expand the field of hyperbaric therapy.

\section{Main text}

The historical definition of HBOT (“...a treatment in which a patient breathes $100 \%$ oxygen ...at... $>1$

\section{Correspondence: paulharchmd@gmail.com}

Section of Emergency Medicine, Department of Medicine, Louisiana State University School of Medicine, 1542 Tulane Avenue, Rm. 452, Box T4M2, New Orleans, LA 70112, USA atmosphere absolute...pressurization should be to $1.4 \mathrm{~atm}$ abs or higher.") [9] focuses solely on the absolute pressure of $100 \%$ oxygen above 1.40 ATA. The 1.4 ATA threshold is both arbitrary and limiting when considering that, by definition, oxygen at 1.399999 ATA would not be hyperbaric oxygen therapy. Yet, there is no published data on a difference in clinical efficacy between 1.40 and 1.399999 ATA oxygen for any diagnosis. Furthermore, any $100 \%$ oxygen exposure greater than ambient atmospheric pressure or between 1.0 and 1.4 ATA, or total pressurization between 1.0 and 1.4 ATA of oxygen-enriched breathing gas $>.21$ ATA oxygen would not be hyperbaric oxygen therapy. This excludes a substantial body of clinical literature [10], especially Russian hyperbaric literature where pressures between 1.1 and 1.4 ATA were common (See abstracts of 7th International Congress on Hyperbaric Medicine, Moscow, 1981). The definition is also limiting by its exclusion of the acknowledged bioactivity of pressure [7, 11]. While relevant in studies where beneficial effects in pressurized air control 
groups have been attributed to the increased partial pressure of oxygen $[12,13]$, it is also relevant to the erroneous claim in DoD studies [3-5] that the 2.0 ATA/ normoxic control group is a sham. Both the sham claim and the historical definition of HBOT are further erroneous when considering that every clinical HBOT is a combination of increasing partial pressure of oxygen and total pressure during pressurization and for at least the first $18 \mathrm{~min}$ of treatment [14], and decreasing partial pressure of oxygen during decompression.

More accurately, the definition of HBOT is a therapy of increased total atmospheric pressure and partial pressure of oxygen over ambient total and oxygen partial pressures $[7,8]$. The bioactivity of increased $100 \%$ total atmospheric pressure oxygen is well known [7-9]. The bioactivity of increased atmospheric pressure is unknown to the clinical hyperbaric medicine community, but well-documented in an extensive basic science literature [11]. Dozens of investigators have reported widespread biological effects of increased pressure across the entire phylogenetic spectrum that begin as early as $30 \mathrm{~s}$ after compression [11].

HBOT In the United States is primarily applied to acute and chronic wound conditions and certain infections [9]. Infections are wound conditions due to the effects of the inflammatory reaction and scar formation. HBOT has a wide range of effects on wound pathophysiology [9]. The daily input of HBOT produces wound healing. HBOT heals wounds by the trophic processes of blood vessel, connective tissue, bone, and skin growth [15-18]. These trophic effects require mitotic activity, however, the intermediary steps for trophism were a void in hyperbaric science until 1997 [19].

Siddiqui, et al. [19] proposed that HBOT was a deoxyribonucleic acid (DNA) signaling agent based on wound-healing synergy of oxygen and growth factors and an HBOT-induced change in the oxygen capacitance of ischemic animal wounds. Multiple studies on HBOT-generated single gene products followed [20-32]. Recently, gene array analyses have demonstrated widespread gene expression/suppression effects of hyperoxia and/or increased atmospheric pressure: 1) Cells grown in 2 ATA air ( .40 ATA oxygen) versus cells in $40 \%$ oxygen at 1 ATA expressed cell adhesion, stress response, transcription, apoptosis, tumor suppressor-related, and mitogen-activated protein kinase-related genes [33], 2) Independent and overlapping genes are sensitive to increases in pressure, oxygen, or both [34], 3) As many as 8101 genes were either up- or down-regulated over $24 \mathrm{~h}$ after a single exposure to HBOT [35] (upregulated genes were primarily growth and repair hormone and the anti-inflammatory genes; downregulated genes were the pro-inflammatory and apoptotic genes), and 4) Differential suppression of inflammatory genes at 1.0,
1.5, and 2.4 ATA oxygen with maximal suppression at 1.5 ATA [36]. While the oxygen studies' results are partially qualified by in vitro:in vivo oxygen partial pressure differences [34, 37], the pressure results are not. The unqualified conclusion is that a substantial number of human genes are sensitive to increased atmospheric pressure, hyperoxia at increased atmospheric pressure, or both.

The lack of appreciation of the dual-component nature of hyperbaric oxygen therapy and the bioactivity of both pressure and hyperoxia at increased atmospheric pressure is widespread, but most evident in the recent DoD trials of HBOT in mTBI PPCS [1-6]. A review in Medical Gas Research [38] correctly mentions that one of the DoD studies does "...not address any potential therapeutic benefit of higher pressures in the absence of increased oxygen tension," however, it does not elaborate on the literature describing bioactivity of pressure. An earlier review [39] mentions only the oxygen component of HBOT. A third review [40] noted, "Unfortunately, agreement that HBOT has a positive effect on TBI has not yet been reached due to the difference in external conditions." Absent in this review was a discussion on the different doses of HBOT used in the various studies and the erroneous assumption in two of the studies that the "sham" groups were not treatment groups that used different doses of hyperbaric therapy. This erroneous assumption is present in all of the DoD mTBI HBOT PPCS studies [7, 8]. When viewed as multi-dose studies the results of the DoD studies become congruent with the results of civilian studies [41-44], suggesting effectiveness of some doses of hyperbaric therapy [1, 6, 41-44], ineffectiveness of others [3-5], and harm of another [2]. This appreciation of dosing differences raises the question of potential effectiveness of many other doses of pressure and hyperoxia in mTBI PPCS. They also spawn a rethinking and re-appraisal of the disputed historical claims of efficacy of HBOT in the treatment of well over one hundred diseases [45] dating to 1662, and the widely differing number of treatable indications in less scientifically restrictive countries, e.g. China [46], versus the United States.

\section{Conclusions}

In conclusion, HBOT is the use of increased total atmospheric pressure and partial pressure of oxygen over ambient total and oxygen partial pressures to treat various disease processes and their diseases. The combination of increased atmospheric pressure and hyperoxia express or suppress upto 8101 genes in human cells [35]. Hyperbaric oxygen therapy appears to be the oldest, most enduring, and most effective gene therapy. Physicians and researchers are playing a symphony with gene expression and suppression, the combination of 
which is dependent on the different total pressures and partial pressures of oxygen. It is apparent that dosing of hyperbaric therapy is in its infancy, particularly in the pressure ranges from 1-2 ATA and across the spectrum of unexplored fractional inspired oxygen concentrations at pressures $\geq 1$ ATA. It is also apparent that multiple doses of hyperbaric therapy are effective in the treatment of PPCS while others are not. With an appreciation of the scientific definition of hyperbaric oxygen therapy the field of Undersea and Hyperbaric Medicine is poised to rapidly expand with investigation of the lower dosing ranges of pressure and hyperoxia for a multitude of diagnoses.

\section{Abbreviations}

ATA: Atmospheres absolute; DNA: DeoxyriboNucleic acid; DoD: United States department of defense; HBOT: Hyperbaric oxygen therapy; mTBI: Mild traumatic brain injury; PPCS: Persistent post-concussion syndrome.

\section{Competing interests}

Paul G. Harch, M.D. owns Harch Hyperbarics, Inc., a small for-profit company that provides expert opinions and hyperbaric medicine consulting. He is also the co-founder of the non-profit International Hyperbaric Medical Association and International Hyperbaric Medical Foundation (IHMF) and the current president and chairman of the board of the IHMF. He has a private practice of hyperbaric medicine at a clinic in which he has no ownership, but derives income from his practice at that site. He is the co-author of The Oxygen Revolution from which he receives royalties.

\section{Author's contributions}

Sole contributor.

\section{Author's information}

M.D. from Johns Hopkins University School of Medicine, Diplomate of the Board of Certification in Emergency Medicine, Diplomate of the American Board of Hyperbaric Medicine, former Fellow of the American College of Hyperbaric Medicine, Clinical Professor of Medicine, LSU School of Medicine, New Orleans. Director of the Department of Hyperbaric Medicine, LSU Health Sciences Center. Former Director of LSU Hyperbaric Medicine Fellowship for 19 years. Co-founder of the International Hyperbaric Medical Association, International Hyperbaric Medical Foundation, and current president and chairman of the board of the International Hyperbaric Medical Foundation.

\section{Received: 30 May 2015 Accepted: 4 July 2015}

\section{Published online: 14 July 2015}

\section{References}

1. Wolf G, Cifu DX, Baugh L, Carne W, Profenna L. The effect of hyperbaric oxygen on symptoms following mild traumatic brain injury. J Neurotrauma. 2012;29:1-7.

2. Scorza KA, McCarthy W, Miller RS, Carne W, Wolf G. Hyperbaric oxygen effects on PTSD and mTBI symptoms: a subset analysis. Abstract C27, Friday, 6/14/2013, 8:12 a.m. Undersea and Hyperbaric Medical Society Annual Meeting, Orlando, FL. https://www.uhms.org/publications/online-store/ publications/product/38-2013-uhms-annual-meeting-programabstracts.html.

3. Cifu DX, Hart BB, West SL, Walker W, Carne W. The effect of hyperbaric oxygen on persistent postconcussion symptoms. J Head Trauma Rehabil. 2013. [Epub ahead of print]. doi: 10.1097/HTR.0b013e3182a6aaf0.

4. Walker WC, Franke LM, Cifu DX, Hart BB. Randomized, Sham-controlled, feasibility trial of hyperbaric oxygen for service members with postconcussion syndrome: cognitive and psychomotor outcomes 1 week postintervention. Neurorehabil Neural Repair. Published online 26 December 2013. http://nnr.sagepub.com/content/early/2013/12/23/1545968313516869.

5. Cifu DX, Walker WC, West SL, Hart BB, Franke LM, Sima A, et al. Hyperbaric oxygen for blast-related post-concussion syndrome: three-month outcomes. Ann Neurol. 2014;75(2):277-86.
6. Miller RS, Weaver LK, Bahraini N, Churchill S, Price RC, Skiba V, et al. Effects of hyperbaric oxygen on symptoms and quality of life among service members with persistent postconcussion symptoms: a randomized clinical trial. JAMA Intern Med. Published online November 17,2014. doi:10.1001/jamainternmed.2014.5479et al.

7. Harch PG. Hyperbaric oxygen therapy for post-concussion syndrome: contradictory conclusions from a study mischaracterized as shamcontrolled. J Neurotrauma. 2013 Oct 11. [Epub ahead of print]. doi:10.1089/neu.2012.2799.

8. Harch P. Department of Defense trials for hyperbaric oxgen and TBI: Issues of study design and questionable conclusions. Undersea Hyperb Med. 2013;40(5):469-70.

9. Gesell LB, editor. Hyperbaric oxygen therapy indications. the hyperbaric oxygen therapy committee committee report. 12th ed. Durham, NC: Undersea and Hyperbaric Medical Society; 2008.

10. Jain KK, editor. Textbook of hyperbaric medicine, 5 th revised and updated edition. Gottingen, Germany: Hogrefe and Huber Publishers; 2008.

11. Macdonald AG, Fraser PJ. The transduction of very small hydrostatic pressures. Comp Biochem Physiol A Mol Integr Physiol. 1999;122(1):13-36.

12. James PB. Hyperbaric oxygenation for cerebral palsy. Lancet. 2001;357(9273):2052-3.

13. Neubauer RA. Hyperbaric oxygenation for cerebral palsy. Lancet. 2001;357(9273):2052

14. Weaver LK, Churchill S, Deru K, Haberstock D. Hyperbaric oxygen for chronic stable brain injury (HYBOBI): Interval to achieve $100 \%$ oxygen of monoplace chamber pressurization to 1.5 ATA (abstract). Undersea Hyperb Med. 2001;38:5. http://archive.rubicon-foundation.org/9941.

15. Marx RE, Ehler W, Tayapongsak P, Pierce LW. Relationship of oxygen dose to angiogenesis induction in irradiated tissue. Am J Surg. 1990;260:519-24.

16. Hehenberger K, Brismar K, Lind F, Kratz G. Dose-dependent hyperbaric oxygen stimulation of human fibroblast proliferation. Wound Repair Regen. 1997;5:147-50.

17. Ueng SW, Lee SS, Lin SS, Wang CR, Liu SJ, Yang HF, et al. Bone healing of tibial lengthening is enhanced by hyperbaric oxygen therapy: a study of bone mineral density and torsional strength on rabbits. J Trauma. 1998:44:676-81.

18. Uhl E, Sirsjo A, Haapaniemi T, Nilsson G, Nylander G. Hyperbaric oxygen improves wound healing in normal and ischemic skin tissue. Plast Reconstr Surg. 1994;93:835-41.

19. Siddiqui A, Davidson JD, Mustoe TA. Ischemic tissue oxygen capacitance after hyperbaric oxygen therapy: a new physiologic concept. Plast Reconstr Surg. 1997;99:148-55.

20. Ishii Y, Miyanaga Y, Shimojo H, Ushida T, Tateishi T. Effects of hyperbaric oxygen on procollagen messenger RNA levels and collagen synthesis in the healing of rat tendon laceration. Tissue Eng. 1999;5:279-86.

21. Yang JT, Chang CN, Lee TH, Lin TN, Hsu JC, Hsu YH, et al. Hyperbaric oxygen treatment decreases post-ischemic neurotrophin-3 mRNA downregulation in the rat hippocampus. Neuroreport. 2001;12(16):3589-92.

22. Lin S, Shyu KG, Lee CC, Wang BW, Chang CC, Liu YC. Hyperbaric oxygen selectively induces angiopoietin-2 in human umbilical vein endothelial cells. Biochem Biophys Res Commun. 2002;296(3):710-5.

23. Freiberger J, Coulombe K, Suliman H, Carraway M, Piantadosi C. Superoxide dismutase responds to hyperoxia in rat hippocampus. Undersea Hyperb Med. 2004;31(2):227-32.

24. Yu Y, Matsuyama Y, Yanase M, Ito S, Adachi K, Satake K. Effects of hyperbaric oxygen on GDNF expression and apoptosis in spinal cord injury. Neuroreport. 2004;15(15):2369-73.

25. Takeyama N, Sakai H, Ohtake H, Mashitori H, Tamai K, Saotome K. Effects of hyperbaric oxygen on gene expressions of procollagen, matrix metalloproteinase and tissue inhibitor of metalloproteinase in injured medial collateral ligament and anterior cruciate ligament. Knee Surg Sports Traumatol Arthrosc. 2007;15(4):443-52

26. Sun L, Marti HH, Veltkamp R. Hyperbaric oxygen reduces tissue hypoxia and hypoxia-inducible factor-1 alpha expression in focal cerebral ischemia. Stroke. 2008;39(3):1000-6.

27. Shyu KG, Wan BW, Chang H. Hyperbaric oxygen activates discoidin domain receptor 2 via tumour necrosis factor-alpha and the p38 MAPK pathway to increase vascular smooth muscle cell migration through matrix metalloproteinase 2. Clin Sci (Lond). 2009;116(7):575-83. 
28. Romero-Valdovinos M, Cardenas-Mejia A, Gutierrez-Gomez C, Flisser A, Kawa-Karasik S, Ortiz-Monasterio F. Keloid skin scars: the influence of hyperbaric oxygenation on fibroblast growth and on the expression of messenger RNA for insulin like growth factor and for transforming growth factor. In Vitro Cell Dev Biol Anim. 2011;47(7):421-4.

29. Gajendrareddy PK, Sen CK, Horan MP, Marucha PT. Hyperbaric oxygen therapy ameliorates stress-impaired dermal wound healing. Brain Behav Immun. 2005;19:217-22.

30. Ferrer MD, Sureda A, Batle JM, Tauler P, Tur JA, Pons A. Scuba diving enhances endogenous antioxidant defenses in lymphocytes and neutrophils. Free Radic Res. 2007:41(3):274-81.

31. Chavko M, Mahon RT, McCarron RM. Mechanisms of protection against pulmonary hyperbaric $\mathrm{O}_{2}$ toxicity by intermittent air breaks. Eur J Appl Physiol. 2007;102:525-32

32. Vlodavsky E, Palzur E, Feinsod M, Soustiel JF. Evaluation of the apoptosisrelated proteins of the $B C L-2$ family in the traumatic penumbra area of the rat model of cerebral contusion treated by hyperbaric oxygen therapy: a quantitative immunohistochemical study. Acta Neuropathol. 2005;110(2):120-6. Epub 2005 Jul 7.

33. Oh S, Lee E, Lee J, Lim Y, Kim J, Woo S. Comparison of the effects of $40 \%$ oxygen and two atmospheric absolute air pressure conditions on stressinduced premature senescence of normal human diploid fibroblasts. Cell Stress Chaperones. 2008;13(4):447-58.

34. Chen Y, Nadi NS, Chavko M, Auker CR, McCarron RM. Microarray analysis of gene expression in rat cortical neurons exposed to hyperbaric air and oxygen. Neurochem Res. 2009;34:1047-56.

35. Godman CA, Chheda KP, Hightower LE, Perdrizet G, Shin D. G, Giardina C. Hyperbaric oxygen induces a cytoprotective and angiogenic response in human microvascular endothelial cells. Cell Stress Chaperones, 2009. doi: 10.1007/s12192-009-0159-0.

36. Kendall AC, Whatmore JL, Harries LW, Winyard PG, Eggleton P, Smerdon GR. Different oxygen treatment pressures alter inflammatory gene expression in human endothelial cells. Under Hyperb Med. 2013;40(2):115-23.

37. Dean JB, Mulkey DK, Garcia III AJ, Putnam RW, Henderson III RA. Neuronal sensitivity to hyperoxia, hypercapnia, and inert gases at hyperbaric pressures. J Appl Physiol. 2003;95:883-909.

38. Davis MC, Shoja MM, Tubbs SR, Griessenauer CJ. Hyperbaric oxygen therapy for chronic post-concussive syndrome. Med Gas Res. 2014;4:8. 9 April 2014.

39. Huang L, Obenaus A. Hyperbaric oxygen therapy for traumatic brain injury. Med Gas Res. 2011;1:21. 6 September 2011.

40. Wang Y, Chen D, Chen G. Hyperbaric oxygen therapy applied research in traumatic brain injury: from mechanisms to clinical investigation. Med Gas Res. 2014;4:18. 4 December 2014.

41. Harch PG, Fogarty EF, Staab PK, Van Meter K. Low pressure hyperbaric oxygen therapy and SPECT brain imaging in the treatment of blast-induced chronic traumatic brain injury (post-concussion syndrome) and posttraumatic stress disorder: a case report. Cases J. 2009;2:6538. http://www.casesjournal.com/search/results?drpField1=\&txtSearch1=\&drp Phrase 1=\&drpField2=\%5BT1\%5D\&txtSearch2=\&drpPhrase2=\&drpField3=\% 5BAU\%5D\&txtSearch3=Harch\&drpPhrase3=\&drpField4=\&txtSearch4=\&drp Phrase4=\&excludeField $1=$ \&excludeSearchText $1=$ \&excludePhrase $1=\& d r p$ AddedInLast $=\& d r p F r o m D a t e=\& d r p T o D a t e=\& d r p O r d e r B y=b y+$ date\&items PerPage $=25 \&$ articleType $=\&$ portal_id $=\&$ jou_id $=10159 \&$ search-button $=\%$ 3CSPAN\%3ESearch\%3C\%2FSPAN\%3E.

42. Harch PG, Andrews SR, Fogarty EF, Amen D, Pezzullo JC, Lucarini J, et al. A phase I study of low-pressure hyperbaric oxygen therapy for blast-induced post-concussion syndrome and post-traumatic stress disorder. J Neurotrauma. 2012;29:168-85.

43. Wright JK, Zant E, Groom K, Schlegel RE, Gilliland K. Case report: Treatment of mild traumatic brain injury with hyperbaric oxygen. Undersea Hyperb Med. 2009;36:391-9.

44. Boussi-Gross R, Golan H, Fishlev G, Bechor Y, Volkov O, Bergan J, et al. Hyperbaric oxygen therapy can improve post concussion syndrome years after mild traumatic brain injury-randomized prospective trial. PLoS One. 2013;8:1-18

45. Gabb G, Robin ED. Hyperbaric oxygen. A therapy in search of diseases. Chest. 1987;92(6):1074-82.

46. Yan L, Liang T, Cheng O. Hyperbaric oxygen therapy in China. Med Gas Res. 2015;5:3. 18 February 2015.

\section{Submit your next manuscript to BioMed Central and take full advantage of:}

- Convenient online submission

- Thorough peer review

- No space constraints or color figure charges

- Immediate publication on acceptance

- Inclusion in PubMed, CAS, Scopus and Google Scholar

- Research which is freely available for redistribution

Submit your manuscript at www.biomedcentral.com/submit 